\title{
SYNTHESIS OF DOUBLE LAYER THIN FILM ZnO/ZnO:Ag BY SOL-GEL METHOD FOR DIRECT BLUE 71 PHOTODEGRADATION
}

\author{
Heri Sutanto $^{1, *)}$, Singgih Wibowo ${ }^{1)}$, Eko Hidayanto ${ }^{1)}$, Iis Nurhasanah ${ }^{1)}$ and Hadiyanto $^{2)}$ \\ ${ }^{1)}$ Department of Physics, Diponegoro University, Indonesia, \\ Jl.Prof Sudharto SH-Tembalang, Semarang 50239, Indonesia \\ ${ }^{2)}$ Department of Chemical Engineering, Diponegoro University, Indonesia, \\ Jl.Prof Sudharto SH-Tembalang, Semarang 50239, Indonesia \\ *Penulis korespondensi : herisutanto@undip.ac.id
}

\begin{abstract}
The objective of this paper is to synthesize and to characterize a single and a double layer (DL) $\mathrm{ZnO}$ and $\mathrm{ZnO} / \mathrm{ZnO}$ :Ag thin films and their application for degradation of direct blue 71. DL thin films were deposited on a substrate glass by sol-gel spray coating technique. Amount of Ag doping (2, 4, 6 and 8 $\%$ mol) onto ZnO were studied. X-Ray Diffractometer (XRD) and UV-Vis spectrophotometer were used to analyze the structure and optical properties of thin films. Direct Blue 71 (DB71) was used for photocatalytic evaluation under UV light irradiation. XRD result showed that all prepared thin films have wurtzite structure crystall with dominant orientation peak was (002) plane. UV-Vis transmittance spectra showed decreasing transparency of films following the DL preparation and Ag doping concentration. By using envelope method, energy gap of films can be determined. $\mathrm{ZnO} / \mathrm{ZnO}$ :Ag 6\% (DL 6\%) indicated the smallest energy gap $3.038 \mathrm{eV}$. The highest DB71 degradation result under $U V$ light irradiation was reached by DL $6 \%$ with $55.43 \%$ and $8.56 \times 10^{-3} \mathrm{~min}^{-1}$ for photocatalytic efficiency and photodegradation rate, respectively.
\end{abstract}

Keywords: band-gap energy; microstructure; photocatalyst; semiconductor; spray coating; transmittance;

\section{Abstrak}

SINTESIS LAPISAN TIPIS DOUBLE LAYER ZnO/ZnO:Ag DENGAN METODE SOL-GEL UNTUK FOTODEGRADASI DIRECT BLUE 71. Tujuan dari paper ini adalah untuk menginformasikan sintesis dan karakterisasi lapisan tipis single dan double layer (DL) ZnO dan ZnO/ZnO:Ag dan aplikasinya untuk degradasi direct blue 71 (DB71). Lapisan tipis DL dideposisi di tas substrat kaca dengan metode sol-gel teknik spray coating. Jumlah doping Ag divariasi (2, 4, 6, dan $8 \%$ mol) dalam $\mathrm{ZnO}$ ini diteliti sifat mikrostruktur dan optiknya. X-ray diffractometer (XRD) digunakan untuk menganalisa mikrostruktur dan UV-Vis spectrophotometer digunakan untuk analisa sifat optik. DB71 digunakan untuk evaluasi kemampuan fotokatalitik dibawah iradiasi cahaya UV dari lapisan tipis hasil sintesis. Hasil uji XRD menunjukkan bahwa seluruh lapisan tipis hasil sintesis mempunyai struktur kristal wurtzite dengan puncak dominan pada bidang (002). Hasil uji UV-Vis menunjukkan bahwa spektrum transmitansi dari lapisan semakin menurun dengan kenaikan konsentrasi doping Ag. Dengan menggunakan metode envelope, celah pita energi dapat ditentukan. DL 6\% menunjukkan celah pita energi terkecil yaitu sebesar 3,038 eV. Kemampuan degradasi DB71 tertinggi dicapai oleh sampel lapisan tipis DL 6\% dengan efisiensi degradasi sebesar 54,43\% dan laju fotodegradasi sebesar $8,56 \times 10^{-3} \mathrm{~min}^{-1}$.

Kata kunci: celah pita energi; mikrostruktur; fotokatalis; semikonduktor; spray coating; transmitansi;

How to Cite This Article: Sutanto, H., Wibowo, S., Hidayanto, E., Nurhasanah, I., and Hadiyanto, (2015), Synthesis of Double Layer Thin Film Zno/Zno:Ag By Sol-Gel Method for Direct Blue 71 Photodegradation, Reaktor, 15(3), 175-181, http://dx.doi.org/ 10.14710/reaktor.15.3.175-181 


\section{INTRODUCTION}

Textile industry such as Batik (traditional cloth from Indonesia) does not only affect to economics development, but also has consequence in environmental problem, especially if its waste water is not treated before discharge into the environment. The waste water generally consists of dye stuff that is hardly degraded. Among these stuffs, Direct Blue 71 (DB71) is considered as the most toxic and hardest degraded (Boumaza et al., 2014; Bulut et al., 2007; Saien et al., 2009).

The application of pretreatment method is required to reduce the toxicity content of this waste. Besides using biological treatment, physical treatment has advantage in long life cycle and relatively fast process. One of the methods is by using photocatallytic process. Photocatalytic process is a degradation method for pollutant by using oxidation process over photocatalyst material such as $\mathrm{TiO}_{2}, \mathrm{Ag}$ $\mathrm{ZnO}, \mathrm{WO}_{3}$. To improve the oxidation process, the selection of photocatalyst material is very important (Al-areqi et al., 2014; Khoa et al., 2012; Chen et al., 2010). The materials produce electrons and holes on conduction band and valence band. The electrons and holes then produce hidroxyl and superoxide ions that effectively will decompose the organic compound.

Zinc Oxide $(\mathrm{ZnO})$ is photocatalyst semiconductor II-VI group with wide direct band-gap $(3.3 \mathrm{eV})$ and highest binding free excitation energy (60 meV) (Poongodi et al., 2015; Nair et al., 2011). $\mathrm{ZnO}$ was abundant, low cost and harmless to environment (Lam et al., 2012). Several study showed the effectiveness of $\mathrm{ZnO}$ is higher than $\mathrm{TiO}_{2}$ in azo dye stuff photodegradation application (Sakthivel et al., 2003). Although photocatayst material in powder form is much more efficient, but it has disadvantages due to separation difficulties and require more time for centrifugation and filtration (Bagheri et al., 2014; Sariouglu et al., 2005). Therefore, the implementation of using thin film is proposed. Several methods to synthesize $\mathrm{ZnO}$ thin films usually use pulsed laser deposition (PLD) (Tarwal et al., 2011), spray pyrolysis (Vijayalakshmi et al., 2008), metal oxide chemical vapour deposition (MOCVD) (Biethan et al., 2012) and sol-gel (Sutanto et al., 2014). Among them, sol-gel spray coating become the best option because it is easy and economically low cost. The improvement of photocatalytic efficiency has been proposed such as introducing $\mathrm{Ag}$ doping into semiconductor (Gouvea et al., 2002; Sutanto et al., 2015). Li et al. (2014) showed that double layer semiconductor could also increase the photocatalytic efficiencies. The objective of this paper were to synthesize and to characterize the double layer thin film $\mathrm{ZnO} / \mathrm{ZnO}: \mathrm{Ag}$ prepared by sol-gel spray coating method. The double layer thin film of $\mathrm{ZnO} / \mathrm{ZnO}: \mathrm{Ag}$ was applied to degrade the pollutant in dyes textile industry especially DB71.

\section{Experimental}

Material

$$
\text { Zinc }
$$

Acetate

dehydrate

( $\left.\mathrm{Zn} .\left(\mathrm{COOCH}_{3}\right)_{2} \cdot 2 \mathrm{H}_{2} \mathrm{O}\right)$, 2-propanol (IPA) and Monoethanolamine (MEA) were used to synthesize $\mathrm{ZnO}$ precursor. Silver acetate $\left(\mathrm{CH}_{3} \mathrm{COOAg}\right)$ was used as $\mathrm{Ag}$ source. Substrate glass for deposition was cleaned using acetone, methanol and de-ionized (DI) water. All chemical was supplied from Merck Germany, except silver acetate from Sigma Aldrich, Swiss. Direct blue 71 (DB71) was triazodirect dye with chemical structure showed in Figure 1 (molecule wieght : $1029,86 \mathrm{~g} / \mathrm{mol}$, C.I. No: $34140, \lambda_{\max }=584$ $\mathrm{nm})$. It was purchased from local dye shop "Jerman" Pekalongan, Indonesia.

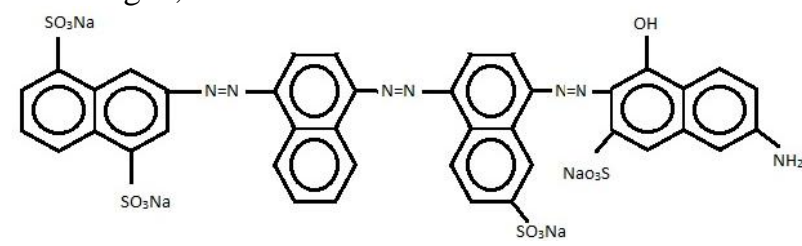

Figure 1. Chemical structure of Direct Blue 71 (DB71)

\section{Preparatin of double layer thin film $\mathrm{ZnO} / \mathrm{ZnO}$ :Ag}

Zinc Acetate was dissolved in 2-propanol (IPA) with solution concentration of $0.5 \mathrm{M}$. The solution stirred for 30 minutes at room temperature. MEA was added into the solution at mol ratio of 1:1 and stirred again for 30 minutes until a clear solution is obtained. In order to make $\mathrm{Ag}$ doping by adding $\mathrm{CH}_{3} \mathrm{COOAg}$ into solution and stirred for next 30 minutes. Doping variation was adjusted for 2, 4, 6 and $8 \%$ mol. The sol-gel precursor was sprayed to glass substrate with temperature $450^{\circ} \mathrm{C}$ and allowed for an hour. For single layer only $\mathrm{ZnO}$ solution was sprayed, while double layer $\mathrm{ZnO}$ :Ag solution was sprayed after $\mathrm{ZnO}$ layer. The prepared thin film was characterized by using Shimadzu XRD 6100/7000 for structure analyzis and mini UV-Vis Shimadzu 1240 SA for optical measurement.

\section{Photocatalytic activity measurements}

DB71 $10 \mathrm{mg} / \mathrm{L}$ solution was made by dilution in water. The dye solution was poured into the box with volume $40 \mathrm{~mL}$ for each sample. The samples were labeled with no photocatalyst, $\mathrm{ZnO}$, $\mathrm{ZnO} / \mathrm{ZnO}$ :Ag (DL 2, 4, 6, and $8 \%$ ). 10 Watt UV lamp was used as photon source. The dye solution was sampled every 15 minutes up to 90 minutes. Photocatalytic eficiency $\left(\mathrm{E}_{\mathrm{f}}\right)$ was calculated by using this equation :

$$
\mathrm{E}_{\mathrm{f}}(\%)=\left(1-\frac{\mathrm{C}_{\mathrm{t}}}{\mathrm{C}_{0}}\right) \times 100 \%
$$

where $\mathrm{C}_{0}$ and $\mathrm{C}_{\mathrm{t}}$ were initial concentration and final concentration of dye solution.

\section{RESULTS AND DISCUSSION Structure Analysis}

XRD pattern of $\mathrm{ZnO}$ pure, $\mathrm{ZnO}: \mathrm{Ag}$ and $\mathrm{DL}$ were showed in Figure 2. There are three main peaks 
in $2 \theta=31.72^{\circ}, 34.42^{\circ}$ and $36.22^{\circ}$ which show lattice orientation (100), (002) and (101), respectively. Figure 2 also showed that $\mathrm{ZnO}$ on the thin films surface have wurtzite structure matched with JCPDS No. \#361451.

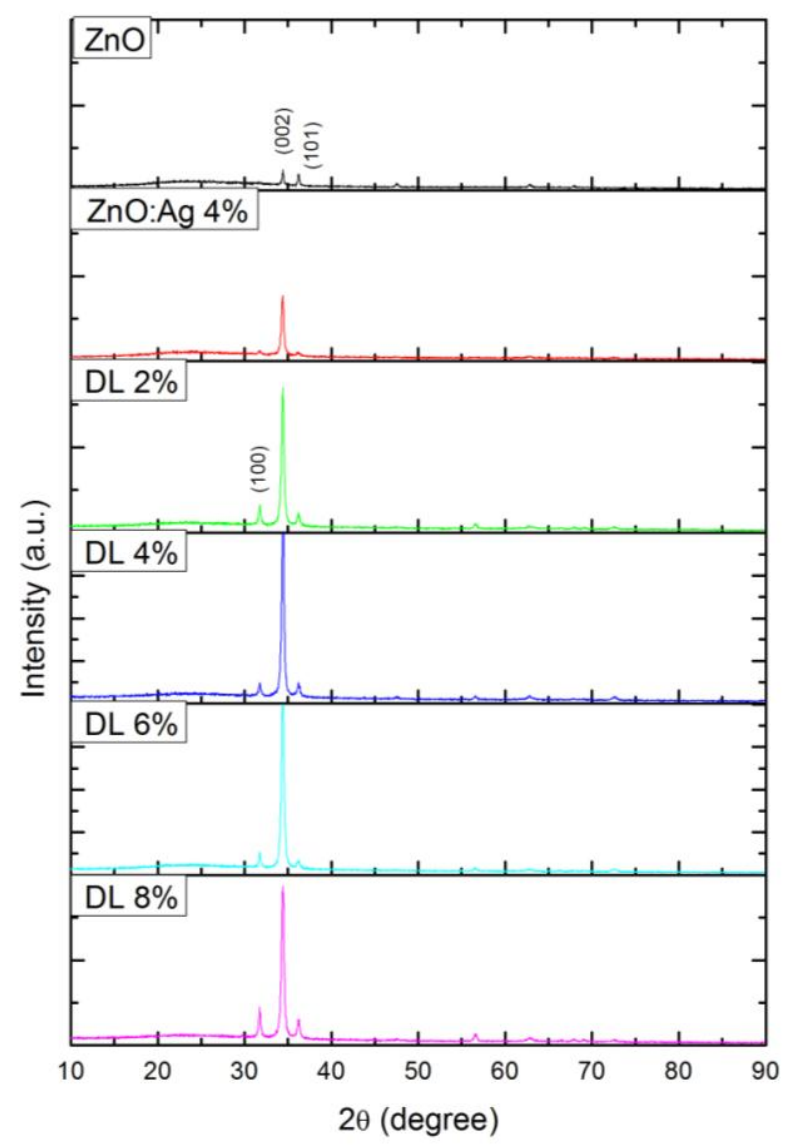

Figure 2. XRD spectra of $\mathrm{ZnO}, \mathrm{ZnO}: \mathrm{Ag} 4 \%$ and $\mathrm{DL}$ $(2 \%, 4 \%, 6 \%$ and $8 \%)$ thin films

In the $\mathrm{ZnO}$ film, the obtained polycrystalline structure. Only two dominant peaks on (002) and (101) orientation, meanwhile (100) did not appear. These both of peaks were shortest than other prepared thin films. The $\mathrm{ZnO}: \mathrm{Ag}$ thin film has better crystalinity than $\mathrm{ZnO}$ film. It was seen by appearance among the three peaks, the (002) orientation shows the highest peak. In the XRD result, crystal quality on double layer thin film is better than single layer thin film.

There was enhancement of main peaks (002) in $\mathrm{ZnO}: \mathrm{Ag} 4 \%$, DL $2 \%$ and DL $4 \%$ films. Meanwhile, in DL $6 \%$ and DL $8 \%$, the crystal quality decreases. It may be caused by replacement of $\mathrm{Zn}^{2+}$ ion (radius of

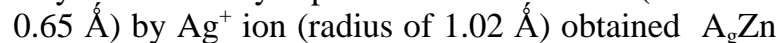
ion (Xu et al., 2015). The existance of $\mathrm{Ag}$ was confirmed by appearance of peak in $2 \theta=56,64^{\circ}$ according to (103) orientation matched by

JCPDS No.\#411402. The average crystallite size of $\mathrm{ZnO}$ was shown on Table 1 . The size was calculated according to Scherrer equation on (002) peak:

$$
d=\frac{0.89 \lambda}{D \cos \theta}
$$

where $\mathrm{d}, \lambda, \mathrm{D}$ and $\theta$ were crystalite size, $\mathrm{x}$-ray wavelength used (1.54016 ̊́), Full Width at Half Maximum (FWHM) and degree of peak, respectively. The crystallite size(grain size) of single layer decreases by introducing $\mathrm{Ag}$ from $24.88 \mathrm{~nm}$ became $20.04 \mathrm{~nm}$ in $\mathrm{ZnO}$ and $\mathrm{ZnO}: \mathrm{Ag} 4 \%$, respectively. In contrast, for double layer, the grain size of thin film increase by increasing $\mathrm{Ag}$ concentration from 19.64$22.01 \mathrm{~nm}$ and the highest grain size was reached by Ag doping of $4 \%$ mol.

\section{Optical measurements}

The prepared thin films showed that they have a fine and homogenous surface (Ilican et al., 2007; Bhira et al., 2000; George et al., 1988). It was seen by fringes pattern on UV-Vis transmittance spectra in Figure 3. The fringes were caused by surface reflection without much absorption on bulk material (Manifacier et al., 1976). Transmittance spectra showed that pure $\mathrm{ZnO}$ thin film has highest transparency about $91 \%$. Transparency decreased in the visible region by addition of $\mathrm{Ag}-4 \% \mathrm{~mol}$ to $78 \%$ and decreased again in double layer thin film from $65 \%$ to $40 \%$ by increasing Ag. This decrease might be caused by scattering of grain boundary and visible light absorption of Ag nanoparticles (Tarwal et al., 2011).

Figure 4 showed the absorbance spectra as a function of wavelength in the $\mathrm{ZnO}, \mathrm{ZnO}: \mathrm{Ag}$ and double layer thin films with doping variation. The $\mathrm{ZnO}$ thin film showed a sharp absorption at wavelength below $380 \mathrm{~nm}$ and after the addition $\mathrm{Ag}$, both single and double layer absorption shifted to higher wavelength (lower energy). It showed that the addition of $\mathrm{Ag}$ shifted the absorption $\mathrm{ZnO}$ spectra. Previously studies (Karyoui et al., 2015; Chen et al., 2013; Bahnemann, 2004) reported that the appropriate wavelength absorption by $\mathrm{ZnO}$ will increase electron transfered from valence band to conduction band. The generated holes were very important for formation of hydroxyl radicals that are used for degradation of pollutants. Absorbance spectra wavelength shifted toward to visible light (red shift) by increasing $\mathrm{Ag}$ on single or double layer. It was seen that double layer $6 \%$ thin film shifted toward to visible light more dominant than others. That means double layer $6 \%$ could absorb larger wavelength spectrum or smaller photon energy. It was so important in photocatalytic application, since visible light responsive photocatalyst was more interesting studies by researchers in this field. 
Table 1. The crystallite size of $\mathrm{ZnO}$ on (002) plane

\begin{tabular}{llllll}
\hline Films & FWHM $(\theta)$ & FWHM $(\mathrm{rad})$ & $\mathrm{d}(\mathrm{nm})$ & $\mathrm{a}(\AA)$ & $\mathrm{c}(\AA)$ \\
\hline ZnO & 0.3305 & 0.0058 & 24.88 & 3.0068 & 5.2079 \\
ZnO:Ag 4\% & 0.4103 & 0.0072 & 20.04 & 3.0094 & 5.2124 \\
DL 2\% & 0.4187 & 0.0073 & 19.64 & 3.0077 & 5.2095 \\
DL 4\% & 0.3737 & 0.0065 & 22.01 & 3.0065 & 5.2074 \\
DL 6\% & 0.4157 & 0.0073 & 19.78 & 3.0079 & 5.2098 \\
DL 8\% & 0.4099 & 0.0072 & 20.06 & 3.0077 & 5.2094 \\
\hline
\end{tabular}

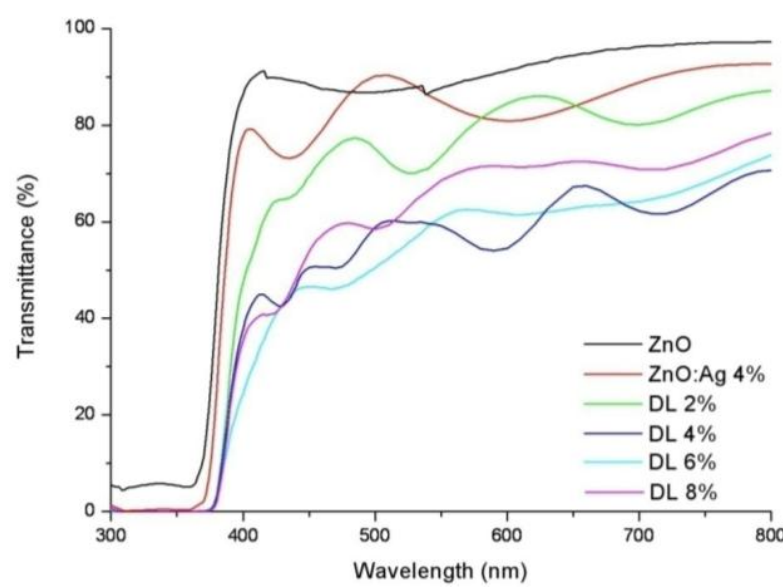

Figure 3. UV-Vis transmittance spectra with various prepared films.

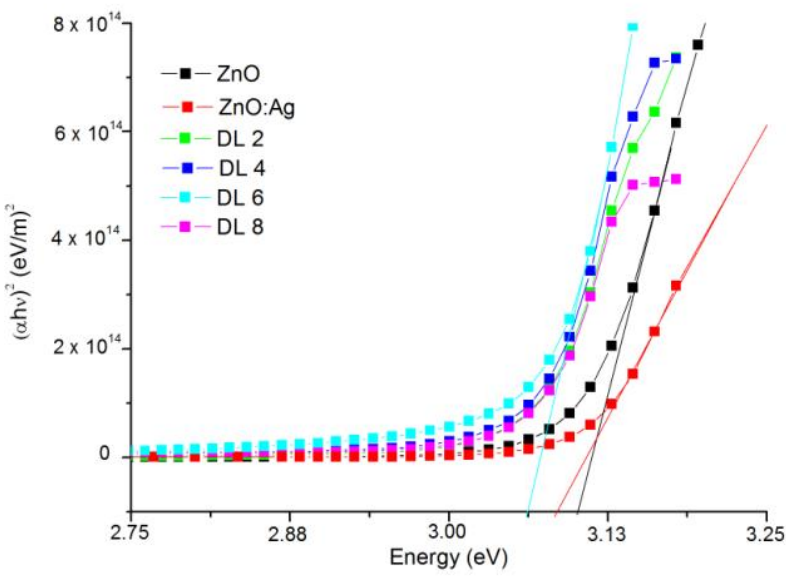

Figure 5. Optical band-gap energy of prepared thin films

In order to calculate direct band-gap of semiconductor, the absorption coefficient and bandgap follow the equation :

$$
(\alpha h v)^{2}=B\left(h v-E_{g}\right)
$$

where $\alpha$ is absoption coefficient, h $v$ is photon energy, $\mathrm{B}$ is constant and $\mathrm{Eg}$ is optical band-gap energy. If a plot $(\alpha h v)^{2} \sim \mathrm{h} v$, Eg can be obtained by linear extrapolation on the curve $(\alpha h v)^{2}=0$. The plot of energy of all prepared thin films was shown in Figure 5. The absorption coefficient $\alpha$ follows the equation :

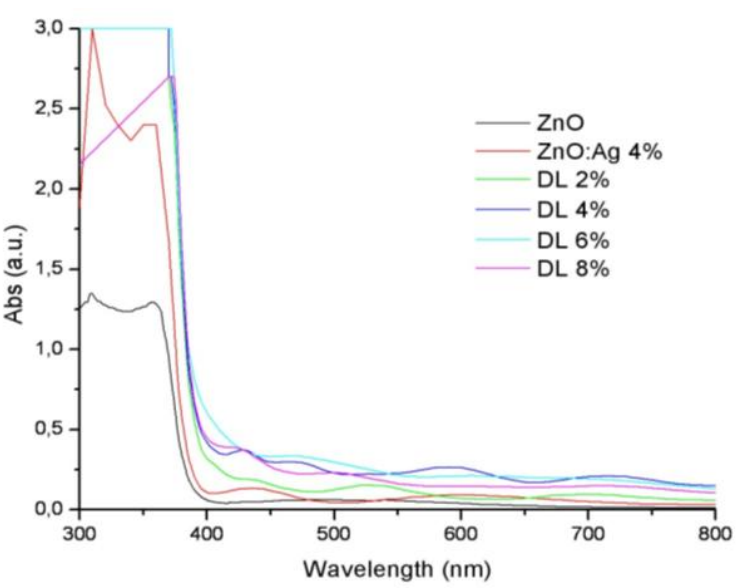

Figure 4. Absorbance spectra with various prepared films

$$
\alpha(v)=2.303 \frac{A}{t}
$$

where A is optic absorbance and $t$ is thickness of film. Optical band-gap energy of $\mathrm{ZnO}$ film was obtained about $3.103 \mathrm{eV}$ smaller than the result was obtained by Tarwal et al. (2011). For Ag doping thin film on single and double layer, the band-gap were about $3.038-3.081 \mathrm{eV}$. Band-gap decreased with increasing $\mathrm{Ag}$ concentration. It indicated that the subtitution of $\mathrm{Zn}^{+}$by $\mathrm{Ag}^{+}$(Jeong et al., 2007).

\section{DB71 photodegradation test}

The photocatalytic activity of thin films $\mathrm{ZnO}$, $\mathrm{ZnO}: \mathrm{Ag}$ and $\mathrm{ZnO} / \mathrm{ZnO}: \mathrm{Ag}$ was indicated by $\mathrm{DB} 71$ degradation under UV irradiation. Figure 6(a) showed decreasing DB71 concentration each interval period. Under UV light, DB71 without photocatalyst showed no significant decrease in concentration. Enhancement photocatalytic activity was shown by double layer with Ag doping in Figure 6(b). The double layer 6\% showed the highest photocatalytic efficiency $\left(\mathrm{E}_{\mathrm{f}}\right)$ c.a. $56.52 \%$ in 90 minutes irradiation. It might due to addition of $\mathrm{Ag}$, the generated electron and hole increased more than pure $\mathrm{ZnO}$. It also resulted in more production of hydroxyl ions and enhaching the photodegradation reaction. In addition, the influence of the double layer inhibited recombination process, so that the oxidation process could take longer. 


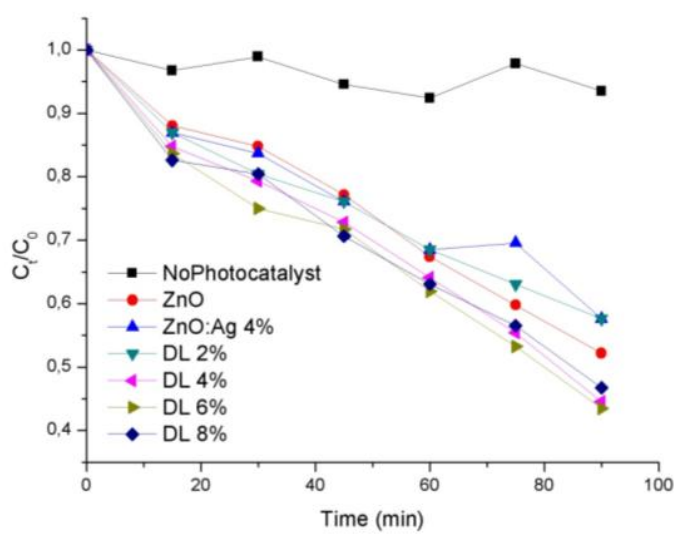

(a)

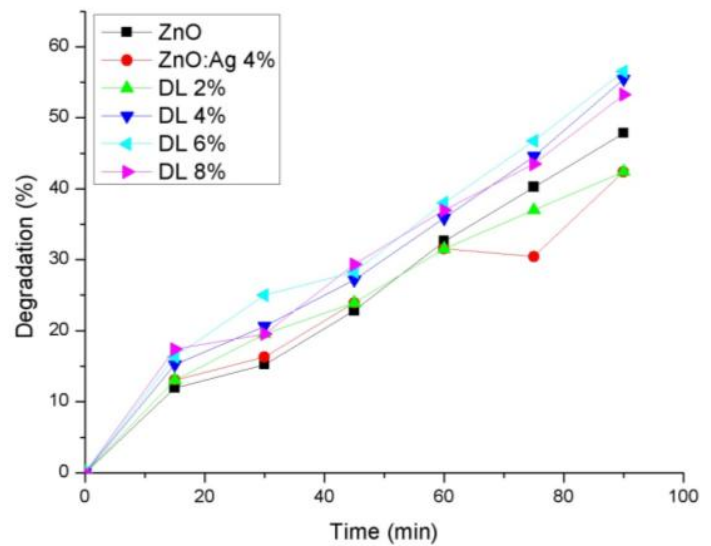

(b)

Figure 6. Photocatalytic degradation (a) and photocatalytic efficiency (b) with various prepared films.

DB71 photocataytic degradation kinetics was described by Langmuir - Hinshelwood models and photocatalytic degradation rate (r) was given by :

$$
r=-\frac{d C}{d t}=\frac{k_{r} K_{d y e} C}{1+K_{d y e} C}
$$

where $\mathrm{dC} / \mathrm{dt}$ is degradation rate $\left(\mathrm{mgL}^{-1} \min ^{-1}\right), \mathrm{C}$ is dye concetration $\left(\mathrm{mgL}^{-1}\right)$ at irradiation time $(\mathrm{t}), \mathrm{k}_{\mathrm{r}}$ is the rate constant $\left(\mathrm{min}^{-1} \mathrm{gL}^{-1}\right)$ and $\mathrm{K}_{\text {dye }}$ is dye adsorption coefficient by catalyst surface $\left(\mathrm{L} \mathrm{mg}^{-1}\right)$. In this study, we used low concentration DB71 dye. The first order kinetic rate with apparent rate constant $\mathrm{k}_{\mathrm{app}}\left(\mathrm{min}^{-1}\right)$ follows this equation (Juang et al., 2010) :

$$
\ln \left(\frac{C_{t}}{C_{0}}\right)=-k_{r} K_{d y e} t=-k_{a p p} t
$$

Apparent rate constant can be determined from slope of the linear plot $-\ln \left(\mathrm{C}_{0} / \mathrm{C}_{\mathrm{t}}\right)$ versus time $(\mathrm{t})$ (Figure 7). Apparent rate constant increase by addition of $\mathrm{Ag}$ in double layer, whereas in single layer decreased. The highest rate constant was achieved by DL 6\%. That means DL 6\% has best degradation rate. Each apparent rate constant of thin films could be seen in Table 2.

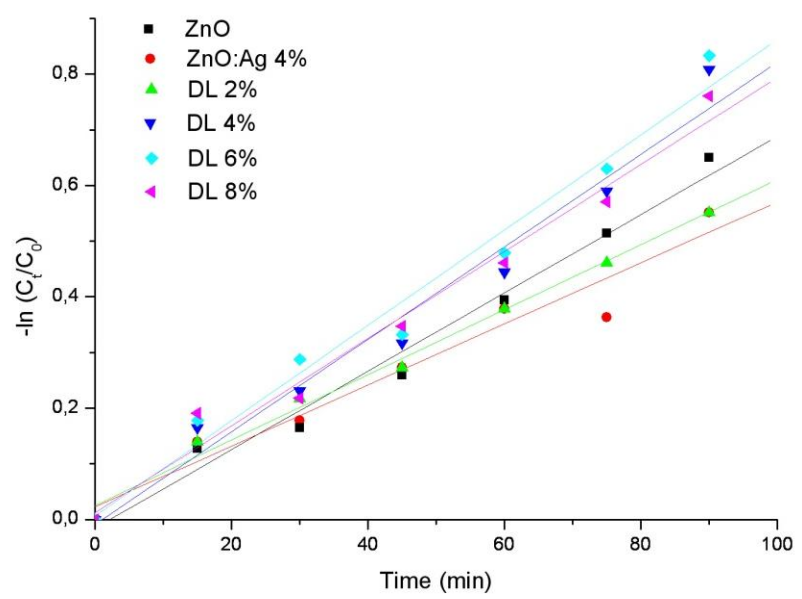

Figure 7. Photodegradation kinetic with various prepared films
Table 2. Apparent rate constant of DB 71 degradation

\begin{tabular}{lll}
\hline Films & $\mathrm{K}_{\text {app }} \times 10^{3}\left(\mathrm{~min}^{-1}\right)$ & $\mathrm{R}^{2}$ \\
\hline ZnO & 7.00 & 0.97901 \\
ZnO:Ag 4\% & 5.48 & 0.9463 \\
DL 2\% & 5.85 & 0.98961 \\
DL 4\% & 8.30 & 0.96683 \\
DL 6\% & 8.56 & 0.97147 \\
DL 8\% & 7.82 & 0.97486 \\
\hline
\end{tabular}

\section{CONCLUSION}

Double layer thin film of $\mathrm{ZnO} / \mathrm{ZnO}: \mathrm{Ag}$ was succesfull deposited on glass substrat by sol gel spray coaing method. All prepared thin films were hexagonal wurtzite structure. The addition of $\mathrm{Ag}$ into $\mathrm{ZnO}$ did not significantly affect the crystal structure, but increase dominant peak in (002) plane. It was also seen that double layer thin films have better crystalinity than single layer. The calculation from Scherrer equation showed that crystallite size of $\mathrm{ZnO}$ have a tendency of getting smaller with addition of single layer from $24.88 \mathrm{~nm}$ on $\mathrm{ZnO}$ and $20.04 \mathrm{~nm}$ on $\mathrm{ZnO}: \mathrm{Ag} 4 \%$ thin film. For double layer thin film have a tendency to increase crystallite size with increasing of $\mathrm{Ag}$ doping from $19.64 \mathrm{~nm}$ to $22.01 \mathrm{~nm}$ with the highest increasing was DL $4 \%$. The band-gap of thin films were getting smaller with addition $\mathrm{Ag}$ in single and double layer and the smallest energy gap was owned by DL $6 \%$. The highest DB71 degradation result under UV light irradiation was reached by DL $6 \%$ with $55.43 \%$ and $8.56 \times 10^{-3} \mathrm{~min}^{-1}$ for photocatalytic efficiency and photodegradation rate, respectively.

\section{ACKNOWLEDMENT}

The authors would like to thank The Ministry of Research, Technology and High Education through Competence Grant 2015 No. 023.04.1.673453/2015 for funding of this work. 


\section{REFERENCES}

Al-Areqi, N.A.S., Al-Alasa, A., Al-Kamalia, A.S.N., Ghaleba, Kh.A.S., and Al-Mureish, K., (2014), Photodegradation of 4-SPPN dye catalyzed by Ni(II)substituted Bi2VO5.5 system under visible light irradiation: Influence of phase stability and perovskite vanadate-oxygen vacancies of photocatalyst, J. Mol. Catal. A : Chem, 381, pp. 1-8.

Bagheri, M., Azizian, S., Jaleh, B., and Chehregani, A., (2014), Adsorption of $\mathrm{Cu}$ (II) from aqueous solution by micro-structured $\mathrm{ZnO}$ thin films, Journal of Industrial and Engineering Chemistry, 20, pp. 2439-2446.

Bahnemann, D., (2004), Photocatalytic water treatment: solar energy applications, Sol. Energy, 77, pp. $445-459$.

Bhira L., Essaidi H., Belgacem S., Couturier G., Salardenne J., Barreaux N., and Bernede J.C., (2000), Structural and photoelectrical properties of sprayed $\beta$ $\mathrm{In}_{2} \mathrm{~S}_{3}$ thin films, Phys. Status Solidi (A), 181, pp. $427-$ 432 .

Biethan, J.P., Sirkeli, V.P., Considine, L. Nedeoglo, D.D., Pavlidis, D., and Hartnagal, H.L., (2012), Photoluminescence study of $\mathrm{ZnO}$ nano-structures grown on silicon by MOCVD, Mater. Sci. Eng.: B, 177, pp. 594-599.

Boumaza, S., Kaouah, F., Hamane, D., Trari, M., Omeiri, S., and Bendjama, Z., (2014), Visible light assisted decolorization of azodyes : direct red 16 and direct blue 71 in aqueos solution on the p- $\mathrm{CuFeO}_{2} / \mathrm{n}$ $\mathrm{ZnO}$ system, Journal of Molecular Catalysis A : Chemical, 393, pp. 156-165.

Bulut, Y., Gozubenli, N., and Aydın, H., (2007), Equilibrium and kinetics studies for adsorption of direct blue 71 from aqueous solution by wheat shells, J. Hazard. Mater. 144, pp. 300-306.

Chen, K.T., Lu, C.S., Chang, T.H., Wu, C.-W., and Chen, C.-C., (2010), Comparison of photodegradative efficiencies and mechanisms of victoria blue $\mathrm{r}$ assisted by nafion-coated and fluorinated $\mathrm{TiO}_{2}$ photocatalysts, J. Hazard Mater. 174, pp. 598-609.

Chen, L., Ta, T., Thuy, T., Huanga, C., Li, J., Yuana, L., and Caia, Q., (2013), Synthesis and photocatalytic application of $\mathrm{Au} / \mathrm{Ag}$ nanoparticle-sensitized $\mathrm{ZnO}$ films, Appl. Surf. Sci. 273, pp. 82-88.

George J., Joseph K.S., Pradeep B., and Palson T.I., (1988), Reactively evaporated films of indium sulphide, Phys. Status Solidi (A) 106, pp. 123-128.

Gouvêa, C.A.K., Wypych, F., Moraes, S.G., Durán, N., and Peralta-Zamora, P., (2000), Semiconductorassisted photodegradation of lignin, dye and kraft effluent by Ag-doped $\mathrm{ZnO}$, Chemosphere, 40, pp. 427-432.

Ilican, S., Caglar, M., and Caglar, Y., (2007), Determination of the thickness and optical constants of transparent Indium-doped $\mathrm{ZnO}$ thin films by the envelope method, Materials Science-Poland, Vol. 25, No. 3.

Jeong, S.H., Park, B.N., Lee, S.B., and Boo, J.H., (2007), Metal-doped $\mathrm{ZnO}$ thin films: synthesis and characterizations, Surf. Coat. Technol. 201, pp. 53185324.

Juang, R.-S., Lin, S.-H., and Hsueh, P.-Y., (2010), Removal of binary azo dyes from water by UVirradiated degradation in $\mathrm{TiO}_{2}$ suspensions, J. Hazard. Mater, 182, pp. 820-826.

Karyaouietal, M., Mhamdi, A., Kaouach, H., Labidi, A., Boukhachem, A., Boubaker, K., Amlouk, M., and Chtourou, R., (2015), Some physical investigations on silver-doped zno sprayed thin films, Materials Science in Semiconductor Processing, 30, pp. 255-262.

Khoa Le, T., Flahaut, D., Foix, D., Blanc, S., Nguyen, H.K.H., Huynh, T.K.X., and Martinez, H., (2012), Study of surface fluorination of photocatalytic $\mathrm{TiO}_{2}$ by thermal shock method, J. Solid State Chem. 187, pp. 300-308.

Lam, S.M., Sin, J.C., Abdullah, A.Z., and Mohamed, A.R., (2012), Degradation of wastewaters containing, organic dyes photocatalysed by zinc oxide : a review, Desalin. Water Treat. 41, pp. 131-169.

Li, C., Hsieh, J.H., Cheng, J.C., and Huang, C.C., (2014), Optical and photoelectrochemical studies on $\mathrm{Ag}_{2} \mathrm{O} / \mathrm{TiO}_{2}$ double layer thin films, Thin Solid Films, 570, pp. 436-444.

Manifacier J.C., Gasiot J., and Fillard J.P., (1976), A simple method for the determination of the optical constants $\mathrm{n}, \mathrm{k}$ and the thickness of a weakly absorbing thin film, J. Phys. E 9, pp. 1002-1006.

Nair, M.G., Nirmala, M., Rekha, K., and Anukaliani, A., (2011), Structural, optical, photo catalytic and antibacterial activity of $\mathrm{ZnO}$ and $\mathrm{Co}$ doped $\mathrm{ZnO}$ nanoparticles, Mater. Lett. 65, pp. 1797-1800.

Poongodi, G., Kumar, R.M., and Jayavel, R., (2015), Structural, optical and visible light photocatalytic properties of nanocrystalline $\mathrm{Nd}$ doped $\mathrm{ZnO}$ thin films prepared by spin coating method, Ceramics International, 41, pp. 4169-4175.

Saien, J., Asgari, M., Soleymani, A.R., and Taghavini, N., (2009), Photocatalytic decomposition of direct red 16 and kinetics analysis in a conic body packed bed reactor with nanostructure titania coated raschig rings, Chem. Eng. J. 151, pp. 295-301. 
Sakthivel, S., Neppolian, B., Shankar, M.V., Arabindoo, B., Palanichamy, M., and Murugesan, V., (2003), Solar photocatalytic degradation of azo dye: comparison of photocatalytic efficiency of $\mathrm{ZnO}$ and $\mathrm{TiO}_{2}$, Sol. Energy Mater. Sol. Cells, 77, pp. 65-82.

Sarioglu, M., Atay, U.A., and Cebeci, Y., (2005), Removal of copper from aqueous solutions by phosphate rock, Desalination, 181, pp. 303-308.

Sutanto, H., Nurhasanah, I., and Hadiyanto, H., (2014), Effect of mn concentration on magnetic and structural properties of GaN:Mn deposited on silicon substrate using chemical solution deposition method, Romanian Journal of Materials, 44 (3), pp. 98-100.

Sutanto, H., Nurhasanah, I., and Hidayanto, E., (2015), Deposition of Ag 2-6 mol\%-doped $\mathrm{ZnO}$ photocatalyst thin films by thermal spray coating method for E. coli bacteria degradation, Materials Science Forum, 827, pp. 3-8.

Tarwal, N.L., and Patil, P.S., (2011), Enhanced photoelectrochemical performance of $\mathrm{Ag}-\mathrm{ZnO}$ thin films synthesized by spray pyrolysis technique, Electrochimica Acta, 56, pp. 6510-6516.

Vijayalakshmi, S., Venkataraj, S., Subramanian, M., and Jayavel, R., (2008), Physical properties of Zinc Doped thin oxide films prepared by spray pyrolysis technique, J. Phys. D: Appl. Phys. 41, pp. 1-7.

Xu, L., Zheng, G., Zhao, L., and Pei, S., (2015), Two different mechanisms on UV emission enhancement in Ag-doped $\mathrm{ZnO}$ thin films, Journal of Luminescence, 158, pp. 396-400. 